\title{
Implementation of Human Resources Management in Tea Plantations in Indonesia: A Case Study - Pt. Perkebunan Tambi Yusuf Enril Fathurrohman ${ }^{* 1}$, Tsaltsa Rossy Muldyana ${ }^{\# 2}$ Associate Professor ${ }^{1}$, Research Scholar ${ }^{2}$ \\ ${ }^{1,2}$ Department of Agribusiness, Faculty of Agriculture and Fisheries Universitas Muhammadiyah Purwokerto, Indonesia \\ ${ }^{\#}$ Corresponding Author E-mail: yusuf.enril@gmail.com
}

\begin{abstract}
Tea is one of the leading plantation commodities in Indonesia. Most of the tea commodities produced today are exported to the international market. The success of tea plantations in facing the dynamics and challenges of course cannot be separated from the implementation of good human resource management where human resource management is aimed at improving the quality of the company's workforce. This paper aims to determine the application of human resource management in a tea plantation company in Indonesia (case study: PT. Perkebunan Tambi). The qualitative research method used in this study used an interactive model and took sources from key informants. The results of this study indicated that PT. Perkebunan Tambi implements human resource management starting from planning, recruitment, selection, socialization or orientation, training and development, performance appraisal to promotion, transfer, and termination of employment to increase productivity and quality of its employees.
\end{abstract}

Keywords — Tea; PT. Perkebunan Tambi; Human Resource Management.

\section{Introduction}

Plantation as one of the agricultural sub-sectors has an important role in Indonesia's agricultural development (Kurniawan et al., 2018). The important role of plantations, among others, is to absorb labor and contribute to gross domestic product (Ariandi et al., 2019). One of the commodities of the Indonesian plantation sub-sector that is interesting to study further is the tea commodity because the domestic tea trade is strongly influenced by various factors including a commodity that can generate substantial foreign exchange (Ramadhani, 2013). Tea is one of Indonesia's leading plantation sub-sector commodities which is exported to international markets. This is because tea is one of the most popular and inexpensive beverages in the world and is consumed by many people, then, due to its increasing demand, tea is considered as one of the main components of the world beverage market (Oktaviana et al. 2017). In addition, Onduru et al (2012) and S. Van der Wal (2008) stated that tea is the most popular and cheapest beverage after water and is an important commodity in terms of employment and export income for several developing countries with tropical climates.

Currently, Indonesia is included in the 7 tea-producing countries in the world after China, India, Kenya, Sri Lanka, Vietnam, and Turkey (FAO, 2019). In Indonesia, the tea commodity is very contributing to generating foreign exchange and employment. Basorudin et al (2019) stated that Indonesian tea production is mostly exported and only a small part is marketed domestically and the number of tea plantation workers is the highest compared to other agribusiness commodities. Even stated by Indarti (2015) that $65 \%$ of the total production is destined for export. However, currently the trend of export volume and the value of Indonesia's exports has decreased (Ariandi et al., 2019; Basorudin et al., 2019) and even the volume of imports has increased (Basorudin et al., 2019). The value and volume of tea exports in Indonesia can certainly be increased in various ways, including understanding the characteristics of the plantation industry, one of which is understanding the applied human resource management.

One of the tea plantation companies in Indonesia is PT Perkebunan Tambi which is located in Wonosobo Regency in the 3rd largest tea-producing province in Indonesia (Central Java Province) (Indarti, 2015). PT Perkebunan Tambi itself manages three plantation units located in Bedakah Village, Tambi Village, and Tanjungsari Village with a total area of 771.8 hectares and produces black tea, green tea, and packaged tea (Pratama \& Nadapdap, 2019). The tea products produced by PT Perkebunan Tambi also have various brands such as petruk tea, cakil, gunung, new petruk, new cakil, black tea bags, green tea bags, corbang fragrant tea, sindoro fragrant tea, red tambi tea, unsorted green tea, BOP, BP II, bohea. Tambi Tea marketing is not only in Wonosobo but has penetrated export markets such as America, Iraq, Germany, New Zealand, United Arab Emirates, Canada, Russia, Egypt, and Pakistan. Not only tea processing and marketing activities, currently PT. Perkebunan Tambi is developing an agro-tourism concept.

Achievement of PT. Perkebunan Tambi amid the dynamics of the tea industry in Indonesia, of course, cannot be separated from the human resources management in it. Human resources (HR) itself is a job function that manages people in an organization by providing various kinds of 
activities and policies and procedures, which relate to the development, utilization, maintenance, maintenance of the right number, and skills, of employees to achieve business goals. (Government of Manitoba, 2016). To manage human resources, a management system is needed or often called human resource management where HR management is part of general management that focuses on elements of human resources (Anwar et al., 2017). The running of good human resource management is shown by the satisfaction of employees who work at PT. Perkebunan Tambi, especially the tea pickers (Komen \& Nadapdap, 2019), and the significant influence of the service quality of the employee of PT. Perkebunan Tambi with a strong relationship with visitor satisfaction (Santoso \& Nadapdap, 2019).

The role of human resource management is indeed very important, especially in the current state of the development of the tea industry in Indonesia, especially at PT. Perkebunan Tambi. Human Resource Management can be thought of as a set of practices intended to lead to the improvement of the quality of a firm's workforce (Hyde et al., 2008). Therefore, the purpose of this study is to determine the application of human resource management in PT. Perkebunan Tambi.

\section{Methodology}

The purpose of this study was to determine the application of human resource management in tea plantations in Indonesia with a case study at PT. Perkebunan Tambi. PT. Perkebunan Tambi was chosen because this company absorbs a lot of human resources which become job opportunities for them. There are about 832 total employees at PT. Perkebunan Tambi are spread across the Board of Directors' offices, UP Bedakah, UP Tambi, and UP Tanjungsari.

Qualitative research methods are used in this study. Qualitative research is one method to obtain an overview of the research foundation, research paradigm, problem formulation, research stages, research techniques, criteria, and data examination techniques as well as analyzing and interpreting data (Moleong, 2013). This research allows us to obtain information about the human resource management process which includes planning, recruitment, selection, socialization or orientation, training and development, performance appraisal to promotion, transfer, and termination of employment. The key informants selected in this study used a purposive sampling method. Key informants include company leaders and several employees who understand the HR management process flow and are involved in it. Secondary data were obtained from archives, documents, and scientific papers from previous research related to our research theme.
The primary and secondary data collected are then processed and analyzed according to the type of problem. Qualitative data were analyzed with an interactive model (Miles \& Michael, 2005). The interactive analysis is a continuous process starting from data search, data reduction, data presentation, to drawing conclusions and verification.

\section{Result and Discussion}

\subsection{Planning}

Human resource planning is a process that involves evaluating past and present developments so that HR management in the company can be optimal. Human Resource Planning can be complex or simple, implicit or explicit, impersonal or personal (George, 2018) depending on each company. According to Cascio (1992), human resource planning can cover the entire organization, or it may be limited to divisions, departments, or groups of ordinary employees. This can be done repeatedly (eg annually) or only sporadically (eg, when launching a new product line or at the start of a capital expansion project).

Conducting HR planning begins by considering the company's goals and strategies with an analysis of internal factors including government regulations and laws, economic conditions, workforce composition or labor patterns, and external factors which include job auditing and job skills, as well as the ability to inventory employee demographics ( Mathis \& Jackson, 2010). The process of human resource planning at PT. Perkebunan Tambi is carried out every six months to ensure the company has sufficient human resources. The planning process begins with an inventory of human resources that already exist in the company, whether there is a need for new employee turnover or not. The unit will report to the Head of the HR Division if there is a vacancy or need a new employee, the HR department will reconsider, if the request is accepted or approved then a new employee recruitment process will be carried out to fill the vacancy.

Things that are noticed by PT. Perkebunan Tambi in the planning process is as follows:

- Mapping the capacity of human resources owned - The first process is carried out by the HR department of PT. Perkebunan Tambi in HR planning is to recognize the capacity of employees that the company now has. HR mapping is carried out by PT. Perkebunan Tambi to find out information about the number of active employees, the number of employees who are retiring, the number of employees whose employees need work improvement, and other employment information. The information was obtained from the Head of Human 
Resources that ensure the human resources within the company are not less or more.

- Estimating the company's HR needs for some time in the future - PT. Perkebunan Tambi will estimate the company's HR needs for some time to come based on the current state of HR and the company. Estimated needs are carried out to determine the integrity of human resources as needed by the company (increasing the number of human resources or improving the quality of human resources). While the estimated availability is carried out by PT. Perkebunan Tambi to find out HR who require work and are ready to be recruited.

\subsection{Recruitment}

Recruitment and selection are one of the basic functions of human resource management (Harky, 2018; Otoo et al., 2018). The definition of recruitment itself is the process of attracting a large number of people who are qualified for a job (Walker et al., 2009). The recruitment process at PT. Perkebunan Tambiwent through several stages until it was accepted as an employee. The recruitment process at PT. Perkebunan Tambi can be seen in figure 1 .

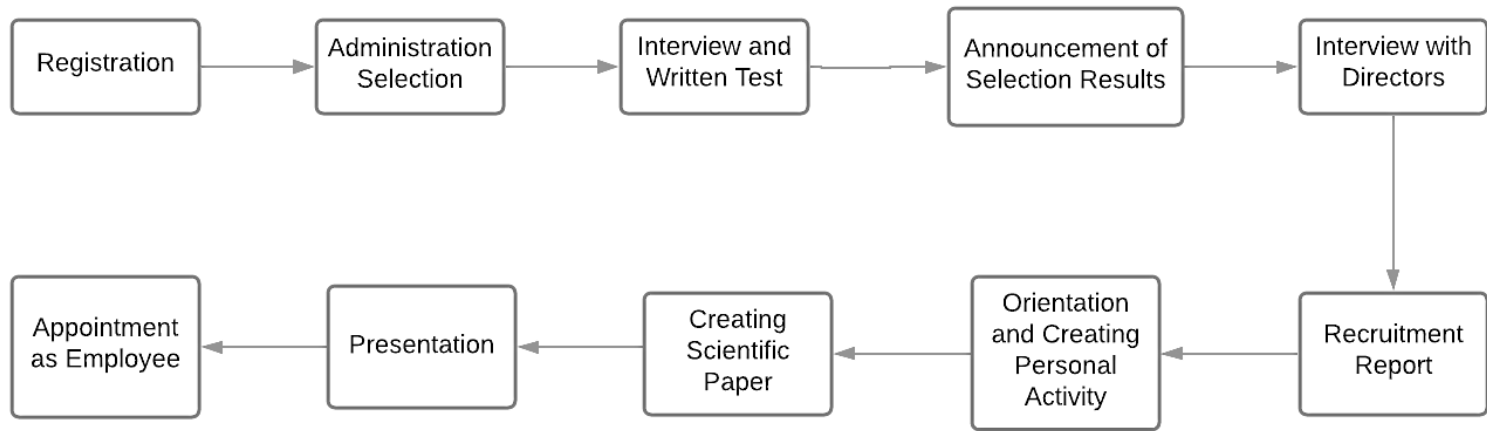

Fig.1: The recruitment process at PT. Perkebunan Tambi

\subsection{Selection}

Selection is the second stage of the work process. Therefore, the selection is the process of identifying the most appropriate and suitable person for a particular job (Otoo et al., 2018). In the process of selecting new employees of PT. Perkebuanan Tambi handed over to the HR department. Furthermore, the HR department will select prospective employees according to the capabilities and specifications set by the company. Selection of prospective employees at PT. Perkebunan Tambi has different criteria in each field. The difference in criteria in selection is adjusted to what position will be filled because the selection is between employee I, employee II, and wholesale employees.

The selection process starts from the administrative stage then prospective applicants who pass will carry out two interviews and a written test according to the field that is currently needed. Interviews were conducted at an early stage (with the HR department) and those who passed will be conducted again at the final stage (with the board of directors). Several assessments of the results of interviews were asked to prospective applicants at PT. Perkebunan Tambi includes 1) formal education; 2) work experience; 3) technical experience; 4) Technical skills; 5) Motivation; 6) cooperation; 7) ethics; 8) communication skills; 9) foreign language ability; 10) self-appearance; 11) leadership ability; and 12) reference checks. Prospective employees who pass will be given an announcement of the selection results via telephone and e-mail directly by the HR Department of PT. Perkebunan Tambi will be followed by medical tests.

\subsection{Socialization or Orientation}

Prospective applicants who pass are still prospective employees and continue with an orientation process for 1-2 years. The prospective employees will undergo an orientation period which is carried out in three Plantation Units namely Bedakah, Tambi, and Tanjungsari before becoming permanent employees. During the orientation period, prospective employees are required to make daily reports, quarterly reports, and at the end of the term prospective employees will write papers and present the results achieved during the orientation period. After being officially presented, the prospective employee becomes a permanent employee. These requirements are also included in the requirements for promotion from employee II who want to become employee I.

\subsection{Training and Development}

Training and development is a function in Human Resources management that is used to fill the gap between current and expected performance (Elnaga \& Imran, 2013). In addition, employee training and development is an

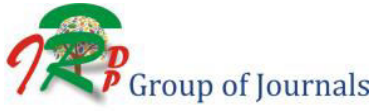


important component of Human Resource planning activities, because it not only maximizes individual profits but can also attract better talent to the organization/company (Bapna et al., 2013).

Training and development at PT. Perkebunan Tambi are distinguished based on the position of employees in the company. For farm employees receive training at the start of work. The form of training for farm employees is in the form of how to pick, which part to pick, when to pick the plants, etc. Farm employees receive training when new technology is used, for example using hand shears or machine shears. Both pieces of training were introduced and implemented to increase and facilitate tea productivity. The training is usually carried out by a farm foreman who is appointed by the head of the Plantation Unit.

Factory employee training is in the form of tea processing training. Factory employee training is not routinely held, only based on need. Apart from training, there are also comparative studies to other companies and visits between Plantation Units. Later, employees who take part in the training will pass on their knowledge to implementers at the factory. For employees I and employees II, job training and development usually attend seminars held by the government or other companies to increase knowledge and knowledge to be applied within the company.

This training and development are very useful for improving the quality of employees from various levels at PT. Perkebunan Tambi. This is in line with (Haryono et al., 2020) which proves that training has a positive and significant effect on work motivation and employee performance.

\subsection{Performance Appraisal}

Performance appraisal is an activity where companies assess or evaluate employee performance. This activity improves performance as well as provides feedback to employees about the implementation of work (Mahardayani \& Dhania, 2016). The given importance of a performance appraisal system arises in part from the nature of today's business environment, which is characterized by the need to achieve organizational/company goals as well as remain relevant in a highly competitive market through superior employee performance (Chen \& Eldridge, 2010). Assessment of work performance at PT. Perkebunan Tambi is carried out every 6 months - once a year to be more effective. So it can be known employees who are productive and less productive. Productive employees can be promoted in their career paths for promotions and salary increases. While less productive employees then take a personal approach so that these employees can improve their performance.
Performance appraisal at PT. Perkebunan Tambi has its criteria and procedures in assessing employee performance. The criteria used can be seen in table 1 .

Table 1. Performance Assessment Criteria for PT. Perkebunan Tambi

\begin{tabular}{|c|c|}
\hline Variables & Attributes \\
\hline Work Quality Factor & $\begin{array}{ll}\text { 1. } & \text { Work Results } \\
\text { 2. } & \text { Punctuality of Work } \\
\text { 3. } & \text { Supervision } \\
\text { 4. } & \text { Trust Level }\end{array}$ \\
\hline Work Quantity Factor & $\begin{array}{ll}\text { 1. } & \text { Volume } \\
\text { 2. } & \text { Time utilization } \\
\text { 3. } & \text { Job arrangement } \\
\text { 4. } & \text { Working time } \\
\text { 5. } & \text { Supervision } \\
\end{array}$ \\
\hline Work Dexterity Factor & $\begin{array}{ll}\text { 1. } & \text { Position knowledge } \\
\text { 2. } & \text { Adaptability } \\
\text { 3. } & \text { Problem-solving ability } \\
\text { 4. } & \text { Punctuality } \\
\text { 5. } & \text { Attendance }\end{array}$ \\
\hline Citizenship Factor & $\begin{array}{ll}\text { 1. } & \text { Work attitude } \\
\text { 2. } & \text { Human relations } \\
\text { 3. } & \text { Criticism and suggestions } \\
\text { 4. } & \text { Punctuality } \\
\text { 5. } & \text { Attendance }\end{array}$ \\
\hline Leadership Factor & $\begin{array}{ll}\text { 1. } & \text { Initiative } \\
\text { 2. } & \text { Planning } \\
\text { 3. } & \text { Analyze } \\
\text { 4. } & \text { Decision making } \\
\text { 5. } & \text { Supervision } \\
\text { 6. } & \text { Coaching/motivation } \\
\end{array}$ \\
\hline
\end{tabular}

The factors assessed as in table 1 have different weights. The assessment is carried out by each appraiser. The value of the work that has been carried out is conducted in the period from January to December which is then converted into salaries/wages and figures. The results of the assessment above are summarized in the conclusion of the Assessment. This performance appraisal is confidential and each assessor is obliged to assess all employees for whom he is responsible fairly and wisely.

\subsection{Promotion, Transfers, and Terminations}

\subsubsection{Promotion}

According to Robert L. Mathis, John H. Jackson, and Sean R. Valentine (2016), promotion is done when an employee is moved from one position to another with rewards, responsibilities, and a higher level in an organization. Meanwhile, Robbins \& Judge (2017) stated that promotion will provide opportunities for personal growth for employees, more responsibility, and an increase in social status. If the promotion is good, it will give satisfaction to employees. Promotion at PT. Perkebunan Tambi adapts to the company's needs. The reason PT. Perkebunan Tambi does promotions usually due to a 
vacancy, an indefinite period depending on the mapping of the company. Mapping and promotion are usually for positions at the level of Section Head and above. As for matters related to promotion, not only from within the company but also from government agencies.

Currently the President Director of PT. Perkebunan Tambi comes from the Wonosobo Regency Government and those who serve as Head of the Board of Directors are from the company. The company leader changes every 5 years and alternates between the Wonosobo Regency Government and PT. Perkebunan Tambi.

\subsubsection{Job Transfer}

Job Transfer is changing in Position/ Job/ Place/ Occupation done both horizontally and vertically (Promotion/ Demotion) in an Organization. Transfers are included in the function of employee development, because it aims to improve work efficiency and effectiveness in a company (Farida et al., 2018). Job Transfer in PT. Perkebunan Tambi is adjusted between education level and position. In addition, there is also consideration of the position of employees in the company for the benefit of company development and improving the quality of human resources. Usually employees of PT. Perkebnunan Tambi located in the Plantation Unit will be transferred to the office of the Board of Directors.

\subsubsection{Work Termination}

A layoff, or termination of a worker's employment, is sometimes a temporary suspension but is often a permanent termination of an employee from their job in the organization. Layoffs and downsizing decisions are not always caused by a specific fault on the part of the employee but are usually a consequence of decreased sales or customers, cash, and/or material resources within the organization (Mujtaba \& Senathip, 2020).

PT. Perkebunan Tambi usually terminates their employment because they have entered their retirement period following the regulations and requirements set by the company. Employees may resign for reasons of 1) health; 2) 55 years old, and; 3) more than 15 years of service. In addition, employees can be dismissed from the company if they have been given a 3rd warning letter for causing problems in the company. As for other reasons, namely 1) 10 consecutive days absent from work; and 2) 5 consecutive days of absence from work, after previously receiving 2 warning letters.

Layoffs at PT. Perkebunan Tambi is implemented to create a conducive climate in the company. This is in line with Neto \& Mullet (2018) that organizational layoffs are designed to increase productivity, economic prospects, and overall competitiveness, and are often considered as the only way to save companies from bankruptcy.

\section{Conclusion}

In this paper, the application of human resource management in one of the plantation companies in Indonesia, PT. Perkebunan Tambi includes planning, recruitment, selection, socialization or orientation, training and development, performance appraisal to promotion, transfer, and termination of employment. The planning process pays attention to several things, such as mapping the capacity of human resources owned and estimating the company's HR needs for some time to come. After the planning process is continued with the recruitment and selection process which consists of several stages until the process of being appointed as permanent employees. Training, Job Assessment as well as promotions, transfers, and layoffs are also applied with certain criteria to increase employee productivity.

\section{References}

[1] R. Kurniawan, I. Purwandari, and P. Purwadi, "Manajemen Pelatihan Di Perkebunan Teh PT. Perkebunan Tambi Wonosobo Jawa Tengah [Training Management In Tea Plantation: PT. Perkebunan Tambi, Wonosobo Central java]," Gastrointest. Endosc. vol. 3, no. 2, 2018.

[2] Y. Ariandi, I. Baroh, and J. T. Ibrahim, "Analisis Trend Ekspor Teh Indonesia [Trend Analysis of Indonesian Tea Exports]," J. Agriecobis, vol. 02, no. 01, pp. 23-31, 2019.

[3] F. Ramadhani, "Daya Saing Teh Indonesia Di Pasar Internasional [Competitiveness of Indonesian Tea in the International Market]," Econ. Dev. Anal. J., vol. 2, no. 4, pp. 468-475, 2013, doi: 10.15294/edaj.v2i4.3214.

[4] N. Oktaviana, M. Masyhuri, and S. Hartono, "Competitiveness of Tea Exports in Asean: A Constant Market Share Analysis," Ilmu Pertan. (Agricultural Sci., vol. 1, no. 2, p. 088, 2017, doi: 10.22146/ipas.10662.

[5] D. D. Onduru, A. De Jager, S. Hiller, and R. Van den Bosch, "Sustainability of smallholder tea production in developing countries: Learning experiences from farmer field schools in Kenya,” Int. J. Dev. Sustain., vol. 1, no. 3, pp. 1-29, 2012.

[6] S. Van der Wal, Sustainability issues in the tea sector: A comparative analysis of six leading producing countries, no. June 2008. Amsterdam, The Netherlands: SOMO- Centre for Research on Multinational Corporation, 2008.

[7] FAO, “Top 10 Country Production of Tea," FAO STAT, 2019. [Online]. Available: http://www.fao.org/faostat/en/\#rankings/ countries_by_commodity.

[8] M. Basorudin, A. Rizqi, S. Murdaningrum, and W. Maharani, "Kajian Persebaran Komoditas Teh: Pengembangan Kawasan Perkebunan Teh Di Provinsi Jawa Barat [Study On The Distribution of Tea Commodities: Development Of Tea Fielding Area In West Java Province In 2015], ’ J. Sos. Ekon. Pertan., vol. 15, no. 3, p. 205, 2019, doi: 10.20956/jsep.v15i3.6792.

[9] D. Indarti, Outlook Teh Komoditas Pertanian Subsektor Perkebunan, vol. 1. 2015.

[10] S. E. Pratama and H. J. Nadapdap, "Strategi Pengembangan Agribisnis Teh PT Perkebunan Tambi Kabupaten Wonosobo [Tea Agribusiness Development Strategy of PT Perkebunan Tambi 
Wonosobo Regency],” J. Penelit. Pertan. Terap., vol. 19, no. 1, p. 19, 2019, doi: 10.25181/jppt.v19i1.1395.

[11] Government of Manitoba, Human Resource Management for Farm Business in Manitoba. Brandon, MB: Manitoba Agriculture, Food and Rural Initiatives, 2016.

[12] N. Anwar, Listiyani, and S. Sastrowiratmo, "Manajemen Sumber Daya Manusia Di Perkebunan Kelapa Sawit Pt. Sawindo Kencana Di Kecamatan Tempilang Kabupaten Bangka Barat [Human Resource Management in Oil Palm Plantation Pt. Sawindo Kencana in Tempilang District, West Bangka Regency]," Agromast, vol. 2, no. 1, pp. 58-66, 2017.

[13] K. Komen and H. J. Nadapdap, "Faktor-Faktor Yang Mempengaruhi Kepuasan Kerja Karyawan Bagian Pemetik Teh Di Pt Perkebunan Tambi, Unit Perkebunan Tambi, Kabupaten Wonosobo [Factors Affecting Work Objectives of Employees in the Tea Picking Division at Pt Perkebunan Tambi, Tambi Plantati," SOCA J. Sos. Ekon. Pertan., vol. 13, no. 3, p. 340, 2019, doi: 10.24843/soca.2019.v13.i03.p05.

[14] I. Santoso and H. J. Nadapdap, "Hubungan Fasilitas, Kualitas Pelayanan, Harga Dan Tempat Terhadap Kepuasan Pengunjung Agrowisata Di Pt Perkebunan Tambi, Kabupaten Wonosobo [The Relationship of Facilities, Service Quality, Price and Place to the Satisfaction of Agrotourism Visitors at Pt," J. Sos. Ekon. Pertan. vol. 15 , no. 2, p. 135, 2019, doi: 10.20956/jsep.v15i2.6648.

[15] J. Hyde, R. Stup, and L. Holden, "The effect of human resource management practices on farm profitability: An initial assessment," Econ. Bull., vol. 17, no. 12, pp. 1-10, 2008.

[16] L. J. Moleong, Metode Penelitian Kualitatif (Qualitative Research Methods). Bandung: PT. Remaja Rosdakarya, 2013.

[17] M. B. Miles and H. A. Michael, Qualitative Data Analysis. Jakarta: UI Press, 2005

[18] V. George, "The Role of Human Resource Planning in Organizational Success," Int. J. Creat. Res. Thoughts, vol. 5, no. 11, pp. $1-10,2018$

[19] W. . Cascio, Managing human resources: Productivity, quality of work life, profits. New York: McGraw-Hill, 1992.

[20] R. L. Mathis and J. H. Jackson, Human Resource Management, 13th Editi. Mason, OH USA: South-Western College Pub, 2010.

[21] Y. F. M. Harky, "The Significance of Recruitment and Selection on Organizational Performance: The Case of Private owned Organizations in Erbil, North of Iraq," Int. J. Contemp. Res. Rev., vol. 9, no. 02, pp. 20393-20401, 2018, doi: 10.15520/ijcrr/2018/9/02/422.

[22] I. C. Otoo, J. Assuming, and P. M. Agyei, "Effectiveness of Recruitment and Selection Practices in Public Sector Higher Education Institutions: Evidence from Ghana," Eur. Sci. Journal, ESJ, vol. 14, no. 13, pp. 199-214, 2018, doi: 10.19044/esj.2018.v14n13p199.
[23] H. J. Walker, H. S. Feild, W. F. Giles, A. A. Armenakis, and J. B. Bernerth, "Displaying Employee Testimonials on Recruitment Web Sites: Effects of Communication Media, Employee Race, and Job Seeker Race on Organizational Attraction and Information Credibility,” J. Appl. Psychol., vol. 94, no. 5, pp. 1354-1364, 2009, doi: $10.1037 / \mathrm{a} 0014964$

[24] A. Elnaga and A. Imran, "European Journal of Business and Management," Int. J. Recent Technol. Eng., vol. 5, no. 4, pp. 137147, 2013, doi: 10.36555/almana.v4i3.1477.

[25] R. Bapna, N. Langer, A. Mehra, R. Gopal, and A. Gupta, "Human capital investments and employee performance: An analysis of IT services industry," Manage. Sci., vol. 59, no. 3, pp. 641-658, 2013 , doi: $10.1287 / \mathrm{mnsc} .1120 .1586$.

[26] S. Haryono, Supardi, and Udin, "The effect of training and job promotion on work motivation and its implications on job performance: Evidence from Indonesia The effect of training and job promotion on work motivation and its implications on job perfor- mance : Evidence from Indonesia," Manag. Sci. Lett., vol. 10, no. March, pp. 2107-2112, 2020, doi: 10.5267/j.msl.2020.1.019.

[27] I. H. Mahardayani and D. R. Dhania, "The Efficacy of Performance Appraisal to Increase Employees 'Job Satisfaction,” J. Educ. Heal. Community Psychol., vol. 5, no. 2, pp. 55-61, 2016.

[28] J. Chen and D. Eldridge, "Are " standardized performance appraisal practices ' really preferred? A case study in China," Chinese Manag. Stud., vol. 4, no. 3, pp. 244-257, 2010, doi: 10.1108/17506141011074138.

[29] P. M. Robert L. Mathis, John H. Jackson, Sean R. Valentine, Human Resource Management, 15th editi. Boston, MA USA: Cengage Learning, 2016

[30] S. P. Robbins and T. A. Judge, Organizational Behavior, Seventeenth Edition, Global Edition. essex, England: Pearson Education Limited, 2017.

[31] Farida, H. Akib, and S. Tahmir, "An Analysis Of Employee Mutation At Personnel And Human Resources Empowerment Agency In Jeneponto District,” IOSR J. Humanit. Soc. Sci., vol. 23 , no. 4, pp. 1-8, 2018, doi: 10.9790/0837-2304010108.

[32] B. G. Mujtaba and T. Senathip, "Layoffs and Downsizing Implications for the Leadership Role of Human Resources," J. Serv. Sci. Manag., vol. 13, no. 02, pp. 209-228, 2020, doi: 10.4236/jssm.2020.132014.

[33] J. M. S. Neto and E. Mullet, "Perceived Acceptability of Organizational Layoffs and Job Alliances During a Recession: A Mapping of Portuguese People's Views," J. Bus. Ethics, vol. 152, no. 4, pp. 1149-1157, 2018, doi: 10.1007/s10551-016-3270-z. 